\title{
AN EXPERIMENTAL INVESTIGATION OF THE EFFECTIVE PARAMETERS ON WET WASHING OF BIODIESEL PURIFICATION
}

\author{
A. Abbaszadeh ${ }^{1}$, B. Ghobadian ${ }^{1 *}$, G. Najafi ${ }^{1}$ and T. Yusaf ${ }^{2}$ \\ ${ }^{1}$ Department of Mechanics of Agricultural Machinery, \\ Tarbiat Modares University, Tehran, Iran. \\ Email: ghobadib@modares.ac.ir \\ Phone: +982148292308; Fax: + 982148292200 \\ ${ }^{2}$ Faculty of Engineering, University of Southern Queensland, Australia
}

\begin{abstract}
The purity level of biodiesel has a strong effect on fuel properties and on engine life. Therefore, a purification step is necessary. Generally, there are two accepted methods for purifying biodiesel: wet washing and dry washing. In this research, the effective parameters on wet purification of biodiesel were investigated. Three types of biodiesel wash water (tap water, distilled water and water with $3 \%$ phosphoric acid), three wet washing temperatures $\left(30,45\right.$ and $\left.60^{\circ} \mathrm{C}\right)$, and three levels of water to biodiesel ratios $(0.5,1$ and $1.5 \mathrm{v} / \mathrm{v})$ were used. In order to perform the wet washing of biodiesel, a bubble washing technique was used. The catalyst, soap and water residue were considered as the criteria to choose the optimum water washing condition and were measured after the wet washing of crude biodiesel. The results showed that the best condition for catalyst and soap removal from biodiesel are acidified water, a temperature of $60^{\circ} \mathrm{C}$ and a water to biodiesel ratio of $1.5(\mathrm{v} / \mathrm{v})$. Also, the least amount of water residue in the final purified biodiesel was observed when using tap water at a temperature of $60^{\circ} \mathrm{C}$ and a water to biodiesel ratio of $0.5(\mathrm{v} / \mathrm{v})$.
\end{abstract}

Keywords: Biodiesel purification; wet washing; catalyst residue; soap residue; water residue.

\section{INTRODUCTION}

The global energy demand, sudden fluctuations of oil prices and environmental concerns due to vehicle exhaust gases are increasing. The most feasible way to solve these problems is to use alternative fuels. Among alternative fuels, biofuels are defined as liquid or gaseous fuels for the transportation sector that are predominantly produced from biomass (Sundar Raj \& Sendilvelan, 2010; Zuhal \& Kemal, 2004). Increasing use of biofuels for energy generation purposes is of particular interest nowadays because they allow reduction of greenhouse gases, provide means of energy security, and may even offer new employment possibilities (Balat, 2008; Kamil, Rahman, \& Bakar, 2011, 2013; Rahim, Mamat, Taib, \& Abdullah, 2012; Soon, Rus, Anika, \& Hasan, 2013). One of these biofuels is biodiesel, which is renewable clean bioenergy as it can be produced from vegetable oils, animal fats and micro-algal oil (Azad, Ameer Uddin, \& Alam, 2012). The properties of biodiesel are quite similar to diesel fuel; thus it is becoming a promising alternative to diesel fuel (Abbaszaadeh, Ghobadian, Najafi, \& Omidkhah, 2012; Nematizade, Ghobadian, \& Najafi, 2012; Rahim et al., 2012). Transesterification is the most common method for biodiesel production, in which triglycerides, as the main component of vegetable oils, react with an alcohol to produce 
fatty acid mono-alkyl esters and glycerol (Dermibas, 2007). One of the advantages of biodiesel is that the feedstocks used to produce it are natural and renewable. All these types of oils come from vegetables or animal fat, making it biodegradable and nontoxic (Marchetti, Miguel, \& Errazu, 2007). In the biodiesel production process, different types of catalysts, such as alkali catalysts, acidic catalysts and enzymatic catalysts, are used (Burton, Fan, \& Austic, 2010; Mumtaz et al., 2012; Parida, Sahu, \& Misra, 2012; Satyanarayana \& Muraleedharan, 2010). However, the alkali catalysts are used mainly in industry, because they improve the transesterification rate especially under moderate reaction conditions (Freedman, Pryde, \& Mounts, 1984). Considering these processes, most biodiesel production processes are not able to produce biodiesel according to related standards (EN14214, ASTM D6751). The purity level of the biodiesel has a strong effect on fuel properties and on engine life. Therefore, a purification step is necessary. Generally, there are two accepted methods for the purification of biodiesel: wet washing and dry washing. Dry washing methods for removing impurities involve the use of adsorbent compounds such as magnesium silicate, ion exchange resin and silica gel (Berrios \& Skelton, 2008; Kucek, César-Oliveira, Wilhelm, \& Ramos, 2007). Wet washing of crude biodiesel with water is used more widely to remove contaminants and chemical residues caused by the transesterification reaction. In this method, a certain percentage of water is added to crude biodiesel and when the water passes through the crude biodiesel it dissolves the impurities. In the next step, contaminated water is removed. This cycle is repeated till the washing water is totally clarified.

Several research works have been carried out on the effective parameters in biodiesel purification. The comparison of different purification methods showed that wet washing is the only way to reduce the residual amount of methanol and glycerin in the biodiesel to the levels specified by EN 14214 standards (Berrios \& Skelton, 2008). Predojević (2008) compared wet washing with hot distilled water to a 5\% phosphoric acid solution. In this study, the effect of the wash method on the biodiesel density, kinematic viscosity, acid value, iodine number, water content, saponification number, cetane index and yield loss were evaluated. It was found that there was no significant change in density, kinematic viscosity, iodine number, water content, saponification number, and cetane index between a distilled water wash and a phosphoric acid wash. It was found that the phosphoric acid wash decreased the acid value to a greater degree, and the phosphoric acid wash produced higher yields than the distilled water wash. He, Gue, and Zhu (2006) conducted experiments using several methods of wet washing. These wash methods included distilled water, $\mathrm{HCl}$ acid wash, solvent extraction, and hollow fiber membrane extraction. This study compared yield loss for each method but did not give information about impurity removal. The three methods of passing water through the crude biodiesel are: mixing, mist washing and bubble washing. Mist washing is the most gentle one, but since it consumes more water, it may not be economical. Therefore, the bubble washing is a better recommendation, although it may increase fuel oxidation at high engine temperature and pressure conditions (Feizollahnejad \& Ghobadian, 2008). Generally, the investigation of effective parameters on the biodiesel purification is strongly required to yield maximum wet washing performance.

In this study, the influence of wet washing parameters on the water, catalyst and soap residues in the final biodiesel are investigated according to requirements given in EN 14214 and ASTM D6751 standards. The investigated parameters in this research work include: type of wash water, water to biodiesel ratio, temperature of wash water and washing time. 


\section{EXPERIMENTAL SETUP}

\section{Materials}

Waste cooking oils were collected from the Tarbiat Modares University (Hetzler \& Seemann, 2006) restaurant, Tehran, Iran and were used as feedstock. A gas chromatograph set (GC, Unicam, UK, 4600), was used for determination of fatty acid components of the waste cooking oil (Table 1). A lower amount of free fatty acid causes lower oxidation and hydrolysis in the transesterification reaction (Çetinkaya \& Karaosmanolu, 2004). When an alkali catalyst was added to these feedstocks, the free fatty acids reacted with the catalyst to form soap and water. The saponification reaction is represented by the general equation given in Figure 1.

Table 1. Fatty acid composition of waste cooking oil used.

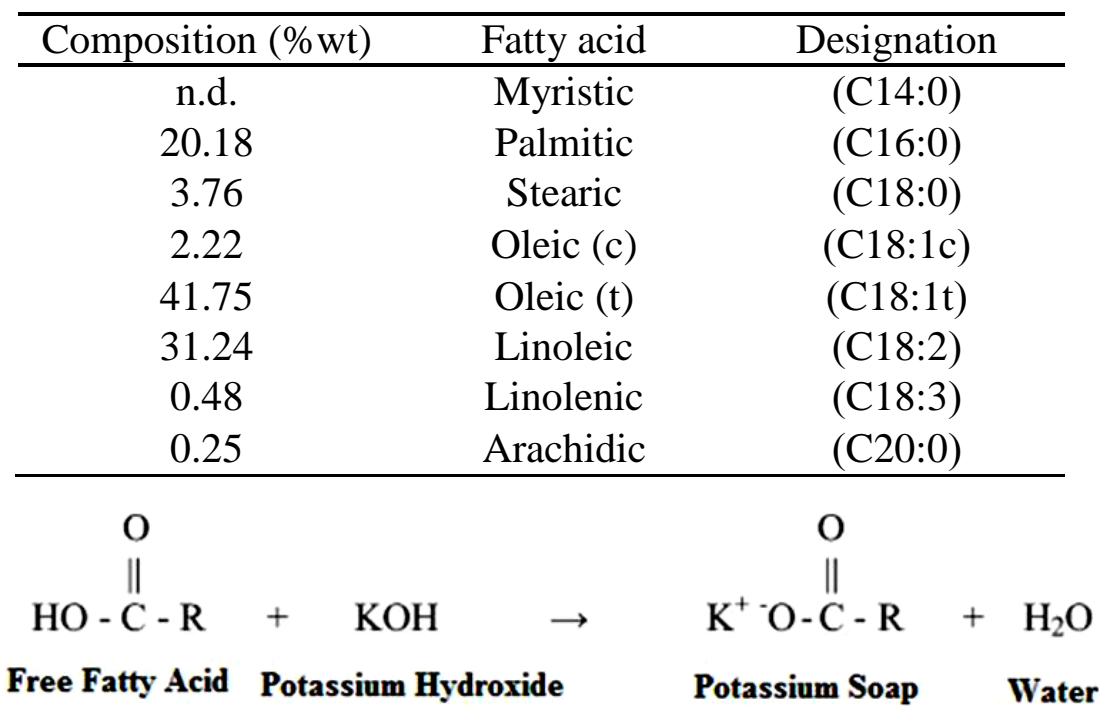

Figure 1. Reaction between free fatty acid and the alkali catalyst.

Before the transesterification reaction, water and impurities were removed from the waste cooking oil to prevent soap formation, oxidation and competing reactions. The sedimentation method was applied for the separation process based on oil heating to $60^{\circ} \mathrm{C}$ and gravitation. In this study, methanol (99.5\% purity), potassium hydroxide $(99 \%)$ and phosphoric acid $(99.5 \%)$ were used.

\section{Experimental Procedure}

\section{Transesterification reaction}

A BioPro 190 processor (USA made) was used to produce crude biodiesel. As the first step, the processed waste cooking oil (refined and free from water) was fed into the system. The existing water in the reaction at higher temperature levels resulted in triglyceride hydrolysis and free fatty acid formation (Cayh \& Kusefoglu, 2008). Free fatty acids neutralized the catalyst and led to soap formation. Therefore, it can be implied that the existence of water and free fatty acids caused soap production. For 
performing the tests, a catalyst of potassium hydroxide (1\% oil weight) and an alcohol to oil volumetric ratio of 1:4 was applied. Since waste oil was being used for biodiesel production, as mentioned, the color of the resulting mixture was dark brown during the early stages of reaction, turning to a lighter color in the later phases of the reaction. The reaction was conducted for 2 hours at a temperature of $60^{\circ} \mathrm{C}$, a mixing speed of $300 \mathrm{rpm}$ and at the pressure environment. The reason for selecting a temperature of $60^{\circ} \mathrm{C}$ was that the temperature of the reaction has to be below the boiling temperature of the methanol $\left(64^{\circ} \mathrm{C}\right)$ (Ghobadian, Rahimi, \& Khatamifar, 2006).

\section{Wet washing of crude biodiesel}

A multi-purpose biodiesel laboratory processor called ILBP3-MF was used for biodiesel purification with the wet washing method (Zenouzi \& Ghobadian, 2007). Figure 2 shows the setup for wet washing using the bubble washing technique. The bubble washing technique is gentler than the mixing method and water drops are utilized efficiently, resulting in a low level of water consumption (Feizollahnejad \& Ghobadian, 2008; Ghobadian, Najafi, \& Nayebi, 2013). The effects of three different types of wash water (tap water, distilled water and water with $3 \%$ phosphoric acid), three levels of water to biodiesel ratios $(0.5,1$ and $1.5 \mathrm{v} / \mathrm{v})$ and three temperatures of 30 , 45 and $60^{\circ} \mathrm{C}$ were examined to determine the effective parameters in crude biodiesel purification. The amount of water, soap and catalyst residue in the final biodiesel product are the major criteria to be analyzed. Additionally, the effect of washing time on the soap and catalyst residue was also investigated for 15 minute intervals and 90 minutes duration.

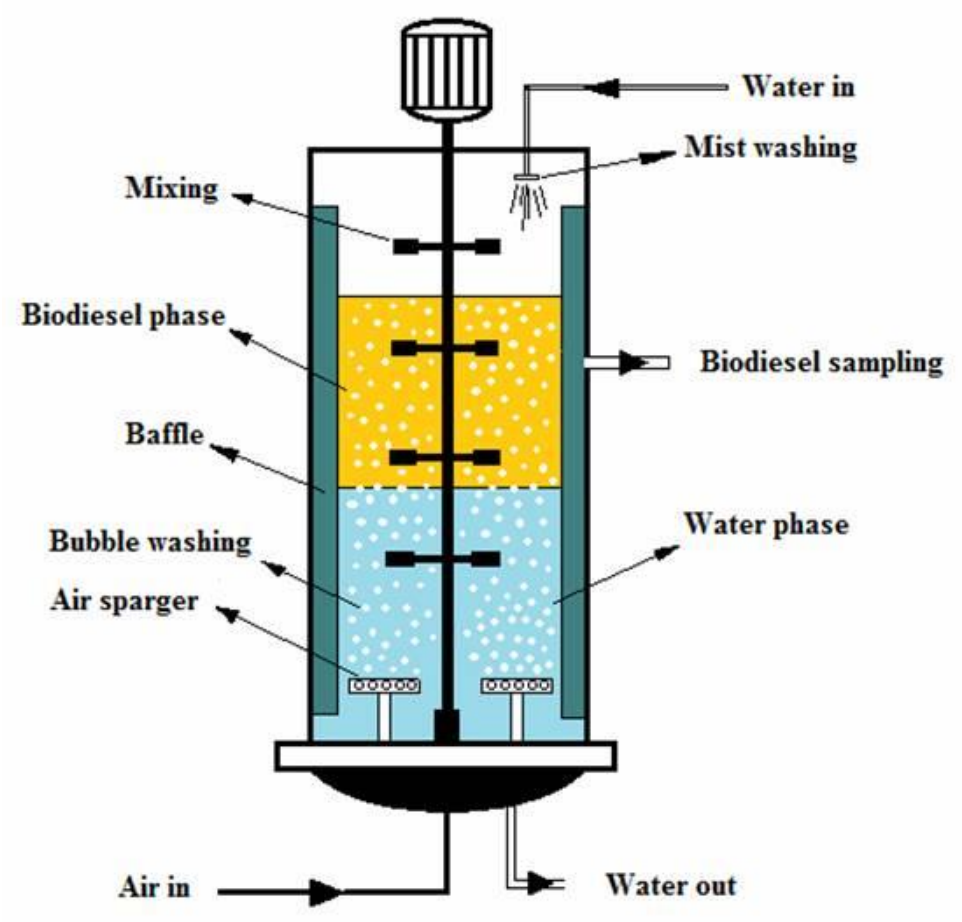

Figure 2. Schematic diagram of the setup used for the wet washing process.

\section{Biodiesel soap and catalyst residue}


There is always some quantity of soap and catalyst left within the crude biodiesel after each transesterification reaction. In this study, the feedstock was restaurant waste cooking oils. Thus, the soap remaining in the produced biodiesel might be considerable. Therefore, it is useful to measure the residues in biodiesel to detect and optimize the effective washing conditions. Hence, the measurement of these residues in biodiesel was carried out by an analytical method based on biodiesel titration in the present research work (Van Gerpen, Shank, Pruszko, Clements, \& Knothe, 2004).

\section{Biodiesel water residue}

Biodiesel water residue leads to hydrolysis (FFA formation) and bacterial growth that may cause engine corrosion (Berrios \& Skelton, 2008). Therefore, there is a limitation in biodiesel standards such as ASTM D-2709 (0.05\%vol) and EN12938 (500 mg/kg) regarding biodiesel water residue. After washing the crude biodiesel for 90 minutes, samples were placed in an oven for 5 hours at a temperature of $75^{\circ} \mathrm{C}$. As the temperature increased, the molecules of water combined more easily and quickly, forming larger water droplets. Subsequently, due to the different densities of water and biodiesel, water was deposited below and biodiesel remained at the top, forming two separate phases. Dewatering is faster when biodiesel contains less water. Therefore, the washing method is suitable whenever the least amount of water is left in biodiesel. Moreover, such a method seems to form less emulsion in the produced biodiesel fuel. To measure the biodiesel water residue in the present research work, the Karl-Fischer method was used. In this method, the amount of water for each sample was determined by using the water and sediment apparatus (Karl Fischer-Ti Stand 703) after oven heating of the purified biodiesel.

\section{Statistical Analysis}

The data were analyzed by analysis of the least significance difference (LSD) test at the 95\% level of probability. All trials were carried out in triplicate and the data were analyzed by SAS 9.1 (SAS Institute Inc., Cary, NC, USA).

\section{RESULTS AND DISCUSSION}

\section{Investigations of Wet Washing Parameters on Catalyst Residue}

The effect of three types of wash water (tap water, distilled water and water with $3 \%$ phosphoric acid) on the catalyst residue ( $\mathrm{ppm}$ ) in biodiesel at various temperatures is shown in Figure 3. The trend and position of curves in Figure 3 shows that wash water with 3\% phosphoric acid had the major effect on the catalyst removal in the final biodiesel product (Knothe, Van Gerpen, \& Krahl, 2005). The results obtained from mean comparison analysis showed that the level of catalyst residue in crude biodiesel was significantly decreased in response to the used wash waters (Table 2). This better removal is because the acid added to the wash water neutralizes the residual catalyst from the transesterification reaction. The catalyst residue in final biodiesel after wet washing ranged between 0.08 and $269.01 \mathrm{ppm}$. Among the conditions tested, application of the water with $3 \%$ phosphoric acid and tap water at all temperature levels had the maximum and minimum effect on catalyst removal, respectively. 


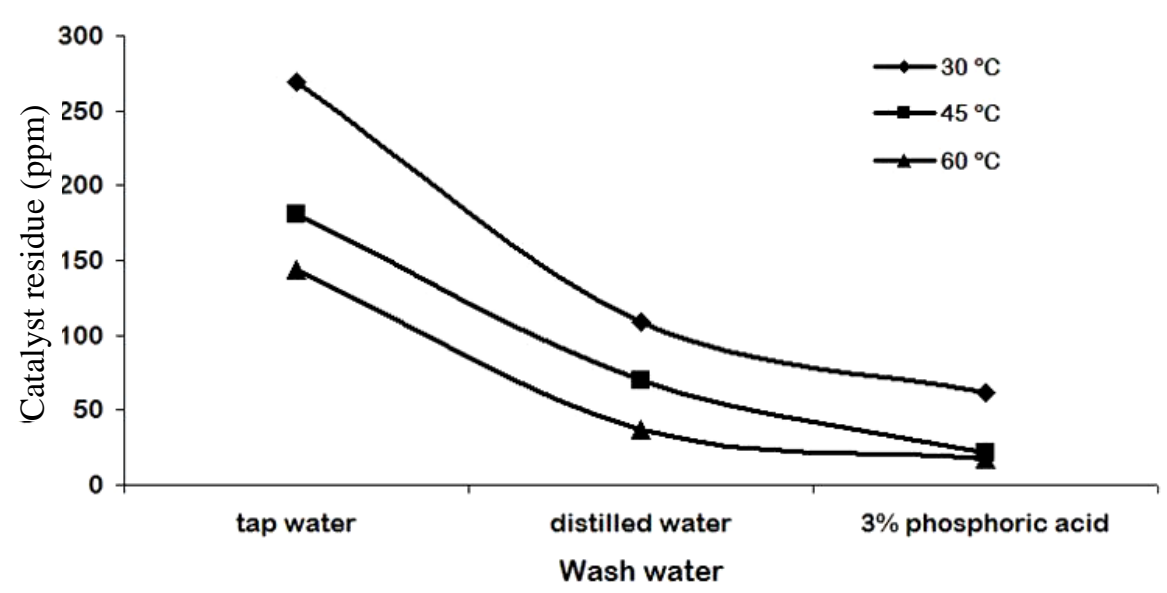

Figure 3. Effect of wash water type on the biodiesel catalyst residue (ppm).

Using multiple regression analysis, a relationship was established between catalyst residue, washing temperature and water to biodiesel ratio in the wet washing process using water with $3 \%$ phosphoric acid (Figure 4 ). The equation and the associated coefficient of determination $\left(\mathrm{R}^{2}\right)$ are given below.

Catalyst residue $=154.64-3.73(\mathrm{~T})+0.026(\mathrm{~T})^{2}-22.77(\mathrm{WB})+2.75(\mathrm{WB})^{2}$

$$
\mathrm{R}^{2}=0.92
$$

In Eq. (1), $\mathrm{T}$ is the washing temperature $\left({ }^{\circ} \mathrm{C}\right)$ and $\mathrm{WB}$ is the water to biodiesel ratio $(\mathrm{v} / \mathrm{v})$.

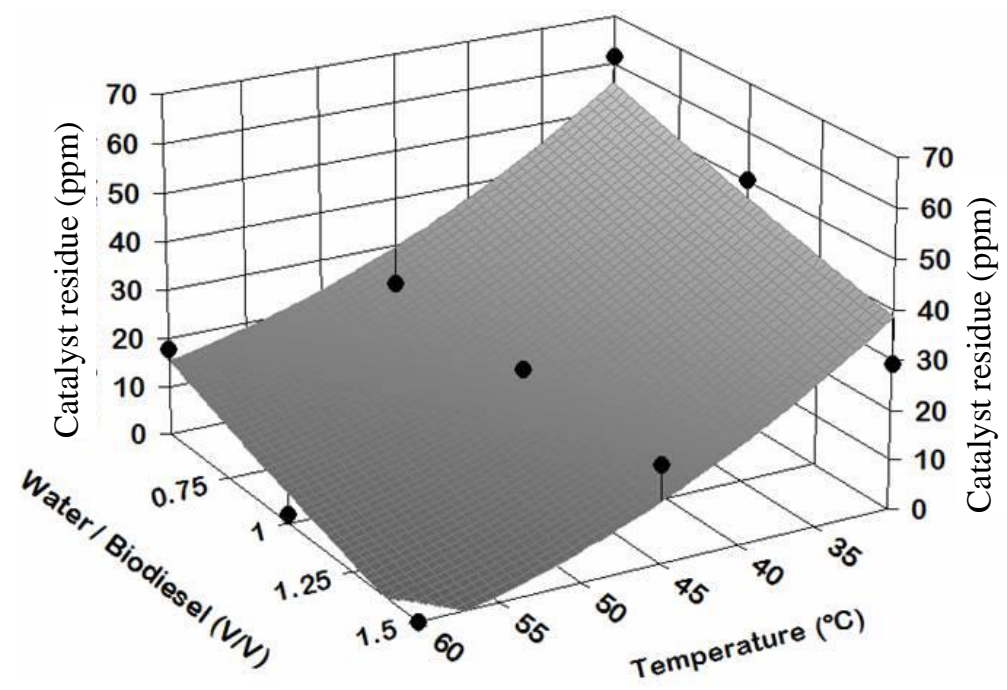

Figure 4. Evaluation of catalyst residue (ppm) against temperature and water/biodiesel ratio in the biodiesel wet washing process when using water with $3 \%$ phosphoric acid.

The obtained results show that increasing the temperature of wash water from $30^{\circ} \mathrm{C}$ to $60^{\circ} \mathrm{C}$ had a significant effect on the catalyst removal from crude biodiesel (Figure 4). Catalyst residue in biodiesel is affected by temperature due to the increased solubility of water in biodiesel, especially when using acidified and distilled water. Regarding the observed results, the least amount of catalyst in the biodiesel was 
observed at a temperature of $60^{\circ} \mathrm{C}$. In the case of water to biodiesel ratio tests, the results show that the catalyst removal was influenced by the amount of wash water used in the wet washing process, and as the water to biodiesel ratio increased, the amount of the catalyst residue in the final product decreased. It is obvious that as the amount of wash water decreases, the wet washing and production costs will be minimized. The objectives of wet washing purification will not be fulfilled if the water to biodiesel ratio is less than the optimized level. This is because using a lower ratio of water to biodiesel increases the number of times the wet washing process must be repeated. Also, the results of statistical analysis proved these findings and showed that water temperature and the water to biodiesel ratio have a significant effect on the levels of catalyst residue in the final purified biodiesel (Table 2).

Table 2. Catalyst, soap and water residue means comparison for water washing parameters using LSD test.

\begin{tabular}{lccc}
\hline & Catalyst residue & Soap residue & $\begin{array}{c}\text { Water } \\
\text { residue }\end{array}$ \\
\hline \multicolumn{1}{c}{ Wash water } & & \\
\hline Tap water & $346.6813^{\mathrm{a}}$ & $2029.076^{\mathrm{a}}$ & $0.0540^{\mathrm{a}}$ \\
Distilled water & $146.1615^{\mathrm{b}}$ & $831.440^{\mathrm{b}}$ & $0.0768^{\mathrm{b}}$ \\
$3 \%$ phosphoric acid & $94.7428^{\mathrm{c}}$ & $548.378^{\mathrm{c}}$ & $0.0647^{\mathrm{c}}$ \\
\hline Temperature $\left({ }^{\circ} \mathrm{C}\right)$ & & & \\
\hline 30 & & & \\
45 & $256.7946^{\mathrm{a}}$ & $1475.350^{\mathrm{a}}$ & $0.0805^{\mathrm{a}}$ \\
60 & $183.9017^{\mathrm{b}}$ & $1091.395^{\mathrm{b}}$ & $0.0654^{\mathrm{b}}$ \\
\hline Water to biodiesel ratio $(\mathrm{v} / \mathrm{v})$ & $146.8893^{\mathrm{c}}$ & $842.150^{\mathrm{c}}$ & $0.0496^{\mathrm{c}}$ \\
\hline 0.5 & & & \\
1 & $229.9833^{\mathrm{a}}$ & $1324.872^{\mathrm{a}}$ & $0.0551^{\mathrm{a}}$ \\
1.5 & $194.0600^{\mathrm{b}}$ & $1098.225^{\mathrm{b}}$ & $0.0658^{\mathrm{b}}$ \\
\hline
\end{tabular}

Means within each column followed by the same letter are not statistically different at $\alpha=0.05$ by LSD test.

\section{Investigations of Wet Washing Parameters on Soap Residue}

The comparison of means showed that the level of soap residue in purified biodiesel was significantly decreased when using all the three types of wash water (Table 2). The experiments showed that the wash water with $3 \%$ phosphoric acid and tap water have the greatest and the least effects on soap removal from biodiesel, respectively. Similarly, Berrios and Skelton (2008), through the comparison of different purification methods (wet washing, ion exchange resins and magnesium silicate), found that soap residue was completely removed by the wet washing method (5\% phosphoric acid). The reason for this significant difference is that the acid in the water splits the chemical bonds of soap formed in the transesterification reaction. In practice, soap in biodiesel reacted with the $3 \%$ phosphoric acid and transformed to soluble salt and free fatty acids. The produced salt was removed in the washing phase, while FFA remained in the biodiesel. The reaction of soap in biodiesel with acid in water is shown in Figure 5. 


\section{$R-\mathrm{CooK}+\mathrm{H} \ldots A C \longrightarrow \mathrm{R}-\mathrm{CooH}+\mathrm{K} \ldots A C$ \\ Potassium Hydroxide $\quad$ Acid $\quad$ Fatty Acid $\quad$ Salt}

Figure 5. The reaction of soap in biodiesel with acid in the water.

Figure 6 shows the results of multiple regression analysis, through which a relationship has been established between the soap residue, washing temperature and water to biodiesel ratio. The relevant equations (Eq. 2) and coefficient of determination are given. Using this equation, the soap residue can be predicted at any given temperature and water to biodiesel ratio.

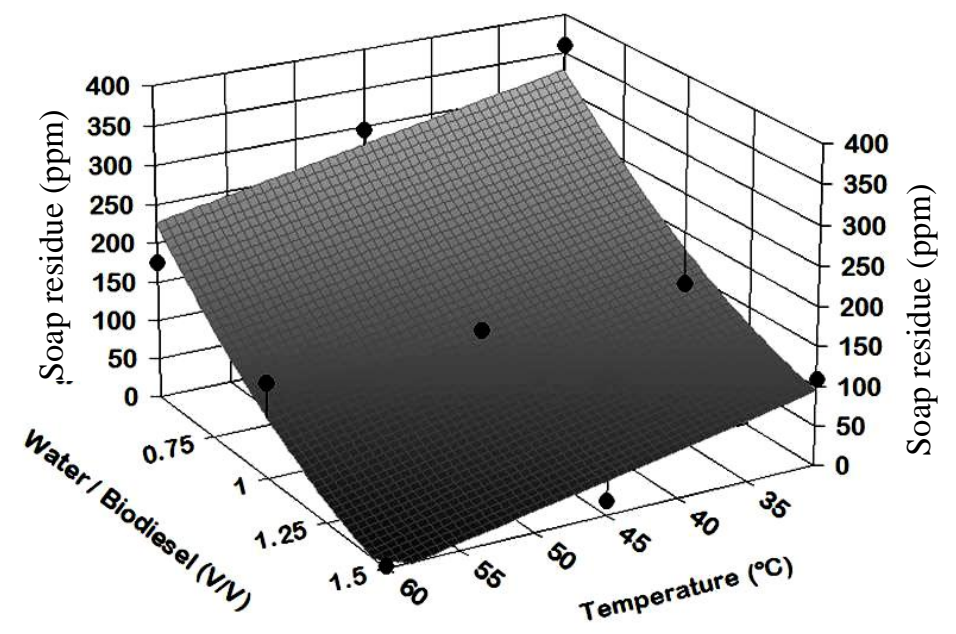

Figure 6. Evaluation of soap residue (ppm) against temperature and water/biodiesel ratio in the biodiesel wet washing process with $3 \%$ phosphoric acid.

$$
\begin{aligned}
& \text { Soap residue }=641.30-3.35(T)-493.35(W B)+130.47(W B)^{2} \\
& R^{2}=0.92
\end{aligned}
$$

In the above equation, $\mathrm{T}$ is the washing temperature $\left({ }^{\circ} \mathrm{C}\right)$ and $\mathrm{WB}$ is the water to biodiesel ratio (v/v). Regarding the statistical analysis, the washing temperature and the amount of wash water have a significant effect on the level of soap residue in the final product (Table 2). According to Figure 6, the comparison of the three investigated washing temperatures indicated that a washing temperature of $60^{\circ} \mathrm{C}$ has the best effect on reduction of soap residue. It seems that this is due to the increased solubility of water in the biodiesel phase. The minimum soap residue in biodiesel regarding the wet washing temperature was $175.81 \mathrm{ppm}$ for $30^{\circ} \mathrm{C}, 121.09 \mathrm{ppm}$ for $45^{\circ} \mathrm{C}$ and $1.05 \mathrm{ppm}$ for $60^{\circ} \mathrm{C}$. The soap residue is not a characteristic of biodiesel that is restricted according to the EU and the ASTM standards, which is why it has not been regularly determined in the relevant literature studies. The comparison of means showed no significant difference between the water to biodiesel ratios of 1 and $1.5(\mathrm{v} / \mathrm{v})$. However, the soap residue was significantly reduced when using the water to biodiesel ratios of both 1 and $1.5(\mathrm{v} / \mathrm{v})$ compared to $0.5(\mathrm{v} / \mathrm{v})$ (Table 2). 


\section{Investigations of Wet Washing Parameters on Water Residual}

Biodiesel contaminated with water causes engine corrosion or reacts with glycerides to produce soaps and glycerol (Predojević, 2008). Therefore, the EN and ASTM standards for biodiesel fuel restricted the water content in biodiesel, setting the maximum allowable content of $0.05 \%$ (i.e. $500 \mathrm{mg} / \mathrm{kg}$ ). In this research work, after the wet washing process the amount of water residue in each test was measured. As can be observed from Figure 7, regardless of the washing temperature when using tap water, the water residue levels in the final biodiesel product are the lowest and range between 0.03 and $0.076(\% \mathrm{~V})$. Additionally, the highest percentages of water residue, 0.05-0.103 $(\% \mathrm{~V})$ were obtained using distilled water. There seemed to be no advantage in using distilled or acidified water in the case of water residue in biodiesel. These observations were the same for all the temperature levels and water to biodiesel ratios. Also, the results obtained from comparison of means proved the experimental findings (Table 2).

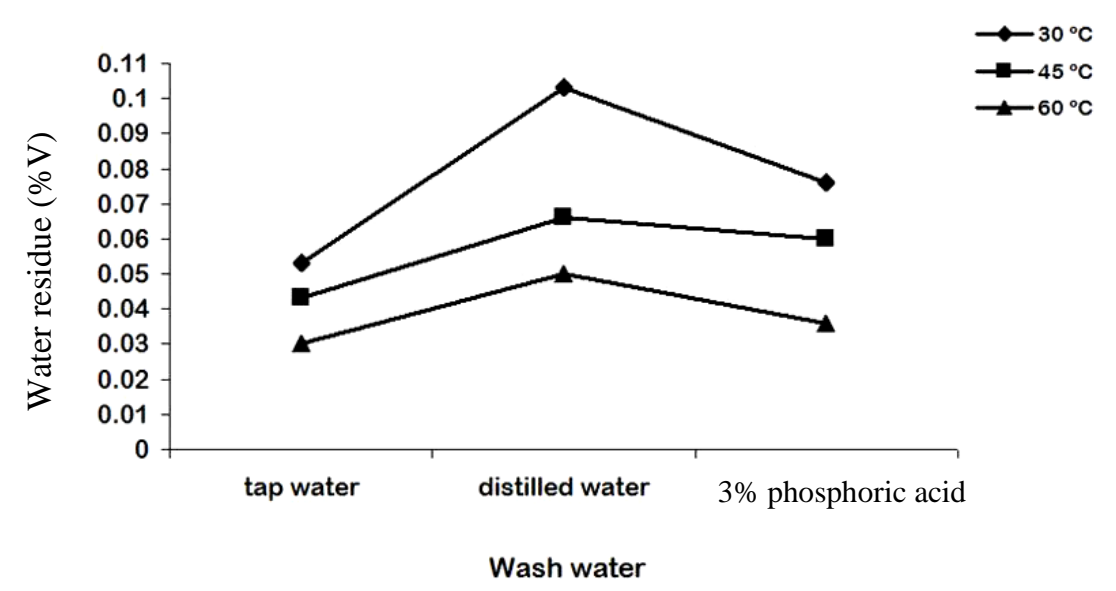

Figure 7. Effect of wash water on biodiesel water residue (ppm).

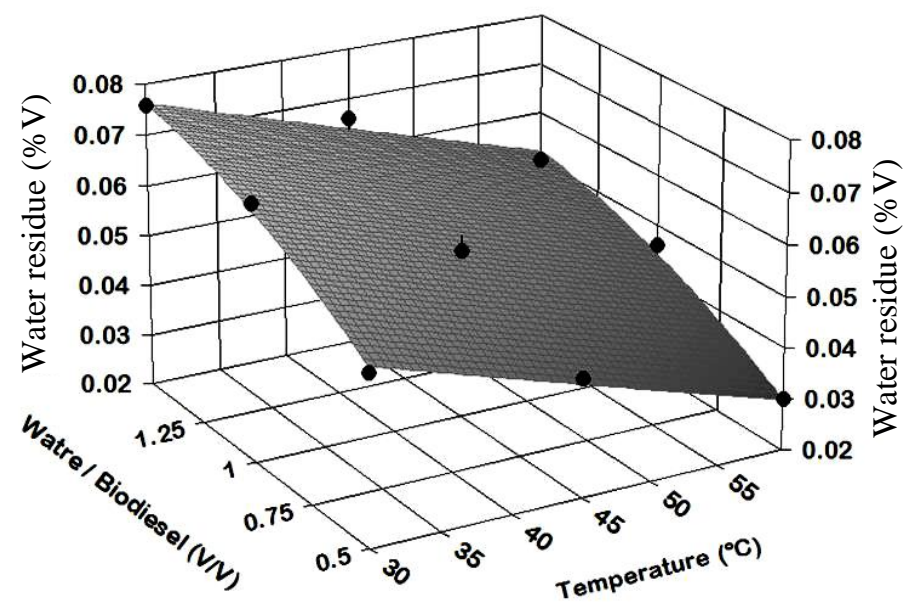

Figure 8. Evaluation of water residue (ppm) against temperature and water/biodiesel ratio in the biodiesel wet washing process with tap water.

According to Eq. (3), multiple regression analysis of the water residue, as a function of washing temperature and water to biodiesel ratio was performed and a relationship was obtained for tap water (Figure 8). Using Eq. (3), the water residue can 
be calculated in terms of two independent variables (temperature and water to biodiesel ratio). Thereafter, the water residue can be predicted using Eq. (3) at any given washing temperature and water to biodiesel ratio.

Water residue $=0.059-0.00088(\mathrm{~T})+7.407 \mathrm{E}-07(\mathrm{~T})^{2}-0.0486(\mathrm{WB})-$ $0.0133(\mathrm{WB})^{2}$

$$
\mathrm{R}^{2}=0.98
$$

In the above equation, $\mathrm{T}$ is the washing temperature $\left({ }^{\circ} \mathrm{C}\right)$ and $\mathrm{WB}$ is the water to biodiesel ratio $(\mathrm{v} / \mathrm{v})$. The mean comparison analysis showed a significant effect of both the water to biodiesel ratio and the washing temperature on the water residue in purified biodiesel (Table 2). During the wet washing process, it was found that as the temperature increased, due to more cohesion of water molecules, the molecules of water combined more quickly together and formed larger water droplets. Therefore, as is obvious from Figure 8, increasing the washing temperature from 30 to $60^{\circ} \mathrm{C}$ leads to a reduction in the amount of water residue in the purified biodiesel. Also, at a washing temperature of $60^{\circ} \mathrm{C}$, regardless of the other test conditions, the biodiesel water residues were found to meet the standard levels at the end of the washing process. Also, Figure 8 depicts the effect of the water to biodiesel ratios on the biodiesel water residue for various washing temperatures. The curves in Figure 8 indicate that when increasing the water to biodiesel ratio at all temperature levels, the water residue in the biodiesel increases. The minimum amount of water residue occurred at a ratio of $0.5(\mathrm{v} / \mathrm{v})$, while the maximum corresponded to the ratio of $1.5(\mathrm{v} / \mathrm{v})$.

\section{Effect of Washing Time on the Catalyst and Soap Residues}

It was found that, at the same washing time, the catalyst and soap residues are the minimums due to using acidified water compared with other water types. The obtained results showed that with longer washing times, the amount of catalyst remaining in the biodiesel decreases. As can be seen from the curves in Figure 9, most of the catalyst (almost 80-90\%) was removed from the crude biodiesel in 45 minutes. Similar results were observed for the soap residues test when using different wash waters.

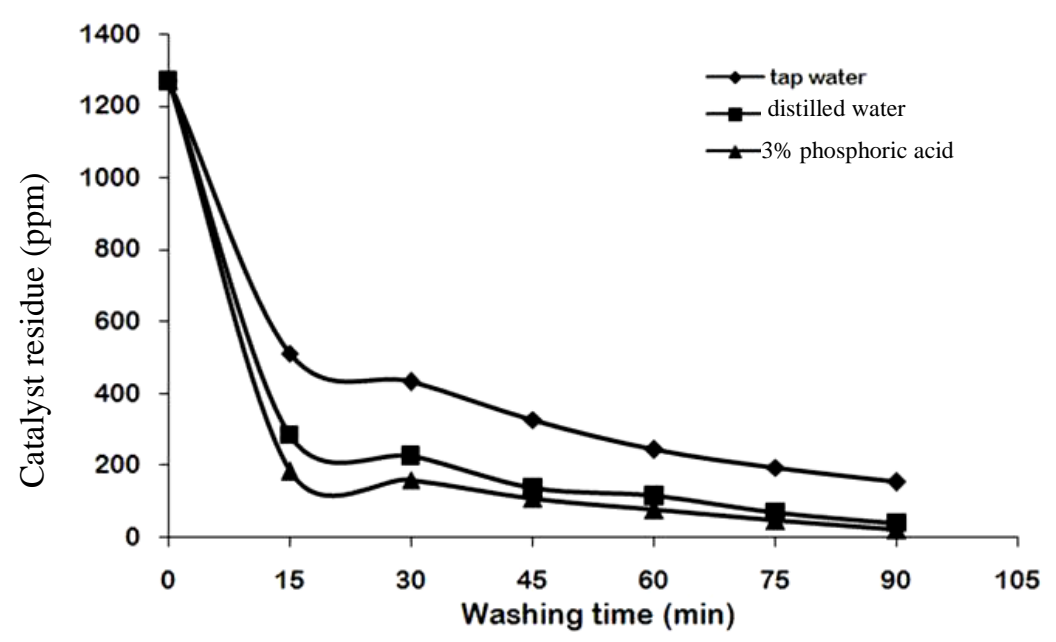

Figure 9. Effect of washing time on the catalyst residue with different wash water types. 


\section{CONCLUSIONS}

In this research work, the effective parameters on biodiesel purification through the wet washing process were investigated. From the results, it was found that acidified water had the best effect on catalyst and soap removal, while in the case of water residue, tap water showed better results. The amounts of catalyst, soap and water residue in the final purified biodiesel were found to be lower when applying a higher washing temperature. It was found that using higher water to biodiesel ratios led to lower levels of catalyst and soap residue in the final purified biodiesel. However, a negative effect was observed on the water residue when using more wash water. The condition of water with $3 \%$ phosphoric acid at a temperature of $60^{\circ} \mathrm{C}$ and a water to biodiesel ratio of 1.5 $(\mathrm{v} / \mathrm{v})$ was found to lead to a lower amount of catalyst and soap residue compared to other wet washing conditions. By using all the wash water types at a temperature of $60^{\circ} \mathrm{C}$ and a consumed water ratio of $0.5(\mathrm{v} / \mathrm{v})$, the residual water level in the final biodiesel product reduced to the required level stated in the ASTM and EN standards.

\section{ACKNOWLEDGMENT}

The authors would like to acknowledge the financial support of the Iranian Fuel Conservation Organization (IFCO) company in carrying out this research work.

\section{REFERENCES}

Abbaszaadeh, A., Ghobadian, B., Najafi, A., \& Omidkhah, O. (2012). Current biodiesel production technologies: A comparative review. Energy Conversion and Management, 63, 138-148.

Azad, A. K., Ameer Uddin, S. M., \& Alam, M. M. (2012). A comprehensive study of di diesel engine performance with vegetable oil: An alternative boi-fuel source of energy. International Journal of Automotive and Mechanical Engineering, 5, 576-586.

Balat, M. (2008). Global trends on the processing of bio-fuels. International Journal of Green Energy, 5, 212-238.

Berrios, M., \& Skelton, R. L. (2008). Comparison of purification methods for biodiesel. Chemical Engineering Journal, 144, 459-465.

Burton, R., Fan, X., \& Austic, G. (2010). Evaluation of two-step reaction and enzyme catalysis approaches for biodiesel production from spent coffee grounds. International Journal of Green Energy, 7, 530-536.

Cayh, G., \& Kusefoglu, S. (2008). Increased yields in biodiesel production from used cooking oils by a two step process: Comparison with one step process by tga. Fuel Processing Technology, 89, 118-122.

Çetinkaya, M., \& Karaosmanolu, F. (2004). Optimization of base-catalyzed transesterification reaction of used cooking oil. Energy Fuels, 18, 1888-1895.

Dermibas, A. (2007). Importance of biodiesel as transportation fuel. Energy Policy, 35, 4661-4670.

Feizollahnejad, M., \& Ghobadian, B. (2008). Modification of biodiesel processor washing vessel. (MSc Thesis), Tarbiat Modares University, Tehran, Iran. 
Freedman, B., Pryde, E., \& Mounts, T. (1984). Variables affecting the yields of fatty esters from transesterified vegetable oils. Journal of the American Oil Chemists Society, 61(10), 1638-1643.

Ghobadian, B., Najafi, G., \& Nayebi, M. (2013). A semi-empirical model to predict diesel engine combustion parameters. Journal of Mechanical Engineering and Sciences, 4, 373-382.

Ghobadian, B., Rahimi, H., \& Khatamifar, M. (2006, 15-16 Feb 2006). Evaluation of engine performance using net diesel fuel and biofuel blends. Paper presented at the The 1st Combustion Conference of Iran (CCI1), Tehran, Iran.

He, H. Y., Gue, X., \& Zhu, S. L. (2006). Comparison of membrane extraction with traditional extraction methods for biodiesel production. Journal of the American Oil Chemists' Society, 83, 457-460.

Hetzler, H., \& Seemann, W. (2006). Friction modes in low frequency disc-brake noise-experimental results and implications on modelling. Proceedings in Applied Mathematics and Mechanics, 6(1), 307-308.

Kamil, M., Rahman, M. M., \& Bakar, R. A. (2011). Performance evaluation of external mixture formation strategy in hydrogen fueled engine. Journal of Mechanical Engineering and Sciences, 1, 87-98.

Kamil, M., Rahman, M. M., \& Bakar, R. A. (2013). Integrated simulation model for composition and properties of gases in hydrogen fueled engine. International Journal of Automotive and Mechanical Engineering, 8, 1242-1155.

Knothe, G., Van Gerpen, J., \& Krahl, J. (2005). The biodiesel handbook. Illinois, USA: AOCS.

Kucek, K. T., César-Oliveira, M. A. F., Wilhelm, H. M., \& Ramos, L. P. (2007). Ethanolysis of refined soybean oil assisted by sodium and potassium hydroxides. Journal of the American Oil Chemists Society, 84, 385-392.

Marchetti, J. M., Miguel, V. U., \& Errazu, A. F. (2007). Possible methods for biodiesel production. Renewable and Sustainable Energy Reviews, 11, 1300-1311.

Mumtaz, M. W., Adnan, A., Mahmood, Z., Mukhtar, H., Malik, M. F., Qureshi, F. A., \& Raza, A. (2012). Biodiesel from waste cooking oil: Optimization of production and monitoring of exhaust emission levels from its combustion in a diesel engine. International Journal of Green Energy, 9(7), 685-701.

Nematizade, P., Ghobadian, B., \& Najafi, G. (2012). Investigation of fossil fuels and liquid biofuels blend properties using artificial neural network. International Journal of Automotive and Mechanical Engineering, 5, 639-647.

Parida, S., Sahu, D. K., \& Misra, P. K. (2012). Preparation of biodiesel using ultrasonication energy and its performance in ci engine. International Journal of Green Energy, 9(5), 430-440.

Predojević, Z. J. (2008). The production of biodiesel from waste frying oils: A comparison of different purification steps. Fuel, 87(17), 3522-3528.

Rahim, R., Mamat, R., Taib, M. Y., \& Abdullah, A. A. (2012). Influence of fuel temperature on a diesel engine performance operating with biodiesel blended. Journal of Mechanical Engineering and Sciences, 2, 226-236.

Satyanarayana, M., \& Muraleedharan, C. (2010). Methyl ester production from rubber seed oil using two-step pretreatment process. International Journal of Green Energy, 7(1), 84-90.

Soon, L. B., Rus, M., Anika, Z., \& Hasan, S. (2013). Continuous biodiesel production using ultrasound clamp on tubular reactor. International Journal of Automotive and Mechanical Engineering, 8, 1396-1405. 
Sundar Raj, C., \& Sendilvelan, S. (2010). Effect of oxygenated hydrocarbon additives on exhaust emission of a diesel engine. International Journal of Automotive and Mechanical Engineering, 2, 144-156.

Van Gerpen, J., Shank, B., Pruszko, R., Clements, D., \& Knothe, G. (2004). Biodiesel analytical methods. .

Zenouzi, A., \& Ghobadian, B. (2007, 5-7 November 2007). Design and fabrication of a multifunction biodiesel processor. Paper presented at the International Congress on Biodiesel. The Science and Technologies, Vienna, Austria.

Zuhal, O., \& Kemal, O. H. (2004). Turkish sugar production potential and use of waste of sugar beet as energy source. International Journal of Green Energy, 1, 381392. 